\section{Reparative Dentin Formation Using Stem Cell Therapy versus Calcium Hydroxide in Direct Pulp Capping: An Animal Study}

Possy Abdelaz ${ }^{1}$, Amira ElZoghbi ${ }^{1}$, Mohamed Shokry² ${ }^{\mathbb{B}}$, Abo-Zeid

Ahmed $^{3}$ D, Hassan Rasha ${ }^{1}$ (D)
'Department of Conservative Dentistry, Faculty of Dentistry, Cairo University, Cairo, Egypt ${ }^{2}$ Department of Surgery, Anesthesiology \& Radiology, Faculty of Veterinary Medicine, Cairo University, Giza, Egypt ${ }^{3}$ Basic Dental Sciences, Dental Research Division, National Research Center, Giza, Egypt

Correspondence : Prof. Mohamed Shokry, Golf City A13 \#4, ElObour, Egypt. Tel:+201068993788. e-mail: mshokry@cu.edu.eg

\begin{abstract}
Direct pulp capping process is a therapeutic method aimed at maintenance of pulp vitality and health by using a biocompatible material placed directly over the exposed pulp. The aim of this study was to evaluate and compare the effect of direct pulp capping procedures by dental pulp stem cells (DPSCs) or calcium hydroxide on dentin tissue formation. Three mongrel dogs were used as experimental model. Two access cavities were prepared in the right and left mandibular fourth premolars in all dogs to expose and extirpate the pulp tissues which were processed in the lab to obtain a single-cell suspensions. The isolated cells were cultures in odontogenic medium for subsequent differentiation. The maxillary teeth (3 incisors and one canine) of the corresponding dog number were subjected to class $V$ cavities to expose their pulps which were assigned into 2 groups of 12 teeth each ( group I - pulp capping with calcium hydroxide) and (group II - pulp capping with dental stem cells DPSCs). The operated teeth were collected after 3 months and processed for histological and electron microscopic examinations. Specimens were subjected to elemental analysis of calcium and phosphorus. EDX elemental analysis revealed significant differences in the calcium and phosphorous wt, $\%$ in the reparative dentin of calcium hydroxide treated group which confirmed histologically. Direct pulp capping by DPSCs has shown promising generative potential for regaining normal dentin.
\end{abstract}

Key Words: pulp capping, dentin, calcium hydroxide, dental stem cells.

\section{Introduction}

Preservation of pulp vitality is a major concern in contemporary restorative dentistry. Direct pulp capping process is a therapeutic method aimed at maintenance of pulp vitality and health by using a biocompatible material placed directly over the exposed pulp during caries removal or because of trauma to seal the pulp and prevent bacterial leakage as well as stimulating dentin bridge formation (1). Many materials able to stimulate pulp tissue repair and reparative dentin formation have been thoroughly investigated in-vivo and in-vitro (2).

In 1920 , calcium hydroxide $\mathrm{Ca}(\mathrm{OH})_{2}$ was introduced to the dental profession and remains the "gold standard" of direct pulp capping materials for several decades because of its antibacterial properties and its ability to stimulate reparative dentin formation (3). However, $\mathrm{Ca}(\mathrm{OH})_{2}$ is reported to suffer from some disadvantages as it is highly soluble, provides a poor seal and the appearance of "tunnel defects" in reparative dentin formed underneath it (4). In addition, when the stimuli to the pulp are strong enough and or rapidly progressing, the terminally differentiated odontoblasts lack the ability to proliferate and to replace injured odontoblasts or to produce new dentin (5). Such clinical challenges make it necessary to look at innovative alternative treatment modalities.
Tissue engineering is an emerging popular domain of bioscience, with the aim of maintaining, restoring and regenerating damaged or lost tissues. Stem cell research is a promising field for tissue regeneration. Postnatal stem cells have been found in a variety of tissues including bone marrow, bone, skin and skeletal muscles. Many studies have exhibited the presence of stem cells in dental tissues, from adult dental pulp tissue, apical papilla, deciduous dental pulp, as well as periodontal ligament (6-8). The dental pulp stem cells (DPSCs) have demonstrated self-renewal and multilineage differentiation capacity into odontoblast-like cells, and produce a mineralized matrix under both in vivo and in vitro conditions $(9,10)$. Previous studies explored the dentin regenerative properties of dental pulp stem cells $(11,12)$, but few studies explored the structure and the mineral content of the newly formed dentin-like structure which is, an important consideration, since small variations in tissue composition can have profound effects on tissue function. The hypothesis of the potential of stem cells to repair a variety of tissue cell types could benefit in regenerative dentistry.

The aim of this study was to evaluate and compare the effect of direct pulp capping procedures by dental pulp stem cells (DPSCs) or calcium hydroxide on dentin tissue formation. 


\section{Material and Methods}

The study was approved by the Institutional Animal Care and Use Committee of Faculty of Dentistry, Cairo University (Protocol 15/5/35). Three 3 mongrel healthy dogs with average weight of $20 \mathrm{~kg}$ and aged between 9-12 months old were used in the present experimental study. The dogs were vaccinated, dewormed and lived in separate boxes in the Faculty of Veterinary Medicine, Cairo University with feeding and water ad libitum.

All procedures were done under IV general anaesthesia. Teeth surfaces were cleaned with saline irrigation followed by swabbing of the mouth by $0.2 \%$ chlorhexidine digluconate. The jaws were opened by using a modified plastic syringe through cutting its upper head. The operation field was isolated by means of rubber dam system with clamps. In each dog, two access cavities were opened in the right and left mandibular fourth premolars (\#408 and \#308-Tiadan system) by using a size 2 round carbide bur (SS White, Rio de Janeiro, RJ, Brazil) at low speed (1200 rpm) under copious saline spray. The pulp tissues were extirpated with a sterile barbed broach. The extirpated pulp tissues were immediately placed in a sterile tube containing phosphate buffered saline and transferred to the laboratory filled with gray mineral trioxide aggregate (MTA). Finally, the coronal portion was restored with selfcure glass ionomer cement.

\section{Stem Cells Isolation and Culture}

The technique of isolation, culture and growth of the pulp cells was according to the described protocol (6). The separated cells were counted under inverted microscope; the cell numbers were multiplied with the sample values to calculate the total cell number. The cells were re-suspended at density of 10.000 cells $/ \mathrm{cm}^{2}$ in complete culture media in sterile $25 \mathrm{~cm}^{2}$ polystyrene cell culture plates which were labelled by date and incubated in the incubator (Sartorius stadium biotech, Gottingen, Germany) at $37{ }^{\circ} \mathrm{C}$ in a humidified atmosphere of $5 \% \mathrm{CO}_{2}$. The medium was changed once every four days. Passaging was performed when primary cell culture of adherent cells reached 70\% confluence and was named passage zero (P0) and later passages were named accordingly. Primary cell cultures of adherent cells were detached by treatment with a sterile solution of $1 \mathrm{~mL}$ Trypsin/EDTA (Lonza, Verviers, Belgium) for $5 \mathrm{~min}$ at $37{ }^{\circ} \mathrm{C}$ in the incubator and were shake intermittently. Complete culture medium with foetal bovine $(100 \mu \mathrm{L})$ serum was added to inactivate the trypsin. The cells were then collected by centrifugation at $2000 \mathrm{rpm}$ for 10 $\mathrm{min}$, and the cell pellet obtained was re-suspended in $1 \mathrm{ml}$ complete medium and divided into two plates (passaging), both followed by immersion in complete culture medium to increase cell numbers. Thus the primary cell culture was propagated and expanded in repeated cell cultures. Cells were sub cultured every other week and culture medium was replaced every 3 days over a 14 day period. All the previous procedures were conducted under aseptic conditions in an air filtered laminar flow safety cabinet (Labconco, Kansas City, USA) using sterile instruments.

\section{Odontogenic Differentiation of Cultured Dpscs}

Cells of the third passage were used for assessing osteogenic differentiation after reaching 70\% confluence level. To provide odontogenic conditions, the culture medium of the confluent cultures of passage 3 was removed and substituted with odontogenic medium consisting of DMEM in addition to $50 \mathrm{mg} / \mathrm{ml}$ L-ascorbic acid (Sigma-Aldrich, UK), 10m M dexamethasone (SigmaAldrich, UK) and $10 \mathrm{~mm} \beta$-glycerophosphate (SigmaAldrich, UK). The differentiation cultures were maintained for 2 weeks. The media was changed every two days $(13,14)$. (Odontogenic differentiation was evaluated by Alizarin Red stain as a biochemical assay to determine colorimetrically the presence of calcific deposits inside the cells of an odontogenic lineage and quantitative. Reverse Transcription-Polymerase Chain Reaction (qRT$\mathrm{PCR}$ ) to detect the production of mineralized matrix and the expression of dentin-specific genes in cultures to analyze the mRNA level of odontogenic differentiation marker respectively. The qRT-PCR assay with the primer was optimized at the annealing temperature.

\section{Direct Pulp Capping Procedures}

A total of 24 teeth (a total of 8 maxillary teeth in each dog/ 4 teeth in each quadrant) were used in 2 groups: Group I: (12 teeth) pulp capping with calcium hydroxide (Dycal). According to the dog number respectively (four left teeth / 3 incisors \#201,\#202 \&\#203 and one canine \#204; Group II: (12 teeth) pulp capping with their harvested autologous dental pulp stem cells (DPSCs).According to the dog number respectively (four right teeth / 3 incisors \# 101, \# 102,\#103 and one canine \# 104).

Three mandibular incisors were taken to evaluate the histological features of their normal pulp.

The pulp capping procedures were performed under general anesthesia and aseptic teeth preparation of the teeth. On the facial surfaces of teeth, class $V$ cavities were prepared (approximately $1 \mathrm{~mm}$ ) coronal to the gingival margin with size 2 round carbide bur at low speed under copious saline spray. The prepared cavities were divided into two groups:

Group I: Calcium hydroxide: Exposure sites were covered with calcium hydroxide using an applicator.

Group II: dental pulp stem cells (DPSCS): After microscopic examination of the cultured cells to check 
cell densities, the old medium was removed and the cultured cells were washed with PBS to remove as much as possible of the extracellular proteins. The cultured cells form tight bridges between them and the surface of the culture flask using proteins. So to dislodge the adherent cells from the flask, trypsin (as a proteolytic enzyme) was used together with EDTA (which engages certain metal ions that may inhibit the activity of trypsin) to break protein bridges (6) Pre-warmed trypsin EDTA solution (0.9 $\mathrm{mL}$ ) at $37{ }^{\circ} \mathrm{C}$ was added to flask that was returned to the incubator again for about 3 min. The flask was rechecked under light microscope to make sure that the adherent cells were lifted off the flask surface (the detached cells appeared rounded after detachment). The cell suspension was transferred to a sterile $15 \mathrm{ml}$ centrifuge tube and spanned down at $2000 \mathrm{rpm}$ for $10 \mathrm{~min}$ in the centrifuge. The supernatant was removed by gentle aspiration to avoid disturbance of the cell pellet. After trypsinization, DPSCs $\left(2 \times 10^{6}\right)$ were seeded on the exposure sites using a pipette, then covered with a pre-autoclaved piece of gold foil. Finally, coronal restoration was performed using Riva self cure glass ionomer cement. The dogs were then kept under constant observation for 3 months. free from the jaws in blocks (tooth/bone) by the use of saw. The teeth were disinfected using $2 \%$ glutaraldehyde and then stored in 10\% buffered formalin for $48 \mathrm{~h}$ after and then stored in 10\% buffered formalin for $48 \mathrm{~h}$ after
removal of the root apex to facilitate fixative penetration.

\section{Histological Evaluation}

After fixation, nine teeth from each group (3 teeth from each dog) were demineralized in 50\% formic acid and $20 \%$ sodium citrate that renewed every 7 days (15). A fine needle was used to perforate specimens to allow formic acid penetration. The specimens were examined weekly for decalcification. The decalcification period was 75 days. After decalcification, samples were dehydrated in $70 \%$ ethanol and then embedded in paraffin blocks, which were serially sectioned in bucco-lingual plane through the capping site into sections of $6 \mu \mathrm{m}$ thickness. All the prepared histological sections were stained with Hematoxylin and Eosin (Hand E) dye and were examined under light microscope for detection of dentin bridge formation and its structure at the magnification power $(40 \times, 100 x$ and $200 \times)$.

\section{Scanning Electron Microscopic Examination and EDAX Analysis}

Three teeth from each group (one tooth from each dog) were embedded in clear acrylic (Acrostone, Cairo, Egypt)

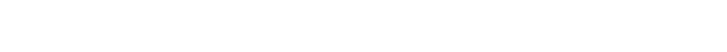

Evaluo
were
wate
. The
dded in
$6 \mu$ sam
stained
dentin b Sacrifice and Tis lingual direction into two sections through the center of the exposure site using mictotome (Technomotori, Italy). Sections were subjected to morphological observation under scanning electron microscopy (SEM) at 150x and $2500 \times$ magnification. Sections were subjected to elemental analysis Using SEM Model Quanta 250 FEG (Field Emission Gun) attached with EDAX Unit (Energy Dispersive analytical (30) K.V. The amount of calcium and phosphorous within both the formed reparative dentin and the normal dentin were measured and were expressed as weight percentage at the area evaluated.

\section{Statistical Analysis}

\section{Results}

Results of Isolation and Identification of Dental Pulp Stem Cells

Dental pulp stem cells (DPSCs) were identified morphologically by their ability to adhere to culture plates in addition to resemblance to fibroblasts (colony forming unit-fibroblastic; CFU-F) with the characteristic spindle shape of cells.

Photomicrographs were taken for cultured cells at 3 , 5, 7, 10, 14 and 21 days: appear indicating successful attachment of cells to culture plates.

At 5 days: cells are increasing in number while assuming
variable morphological appearance from spindle to stellate shaped cells. colony increasing in size with time. to initiation of differentiation .

\section{Results of DPSCS - Odontogenic Differentiation Potential} This part was conducted to evaluate the capacity of DPSCs to differentiate into odontoblast-like cells under the influence of an odontogenic medium.

Results showed that DPSCs have the ability to differentiate into odontoblast-like cells. After one week into blocks and were cut longitudinally in the bucco-
$X$-ray) (FEl company, Netherlands) with accelerating voltage
At 5 days: cells are increasing in number while assuming
variable morphological appearance from spindle to stellate At 7 days: DPSCs starting to form colonies and DPSCs

After 10 days: increase in DPSCs number is evident.

After 14 days: DPSCs reaching 70\% confluence.

At passage 3 of DPSCs: cells are fully confluent prior

\footnotetext{
At 3 days: scattered spindle shaped cells started to
} 
of induction, cells were started to lose the spindle shaped appearance and showed a polygonal shape of differentiated cells. Following two weeks of induction, most of the cells have lost the spindle shaped appearance and become polygonal in shape (Fig. 1A,B).

\section{Alizarin Red Stain}

DPSCs showed positive Alizarin red Staining after two weeks of odontogenic differentiation. The presence of orange red nodules stains is indicative of mineralized matrix formation and successful differentiation (Fig. 1C).

DPSCs odontogenic differentiation was assessed by quantitative reverse transcription polymerase chain reaction ( $q R T-P C R)$

Results of qRT-PCR indicated that dentin sialophosphoprotein DSPP gene was highly expressed in the differentiated DPSCs in comparison to the control gene.

\section{Results of Scanning Electron Microscopy Data and the EDAX Elemental Analysis}

Normal Dentin Structure (control): Figure 2A shows the structure and EDAX elemental analysis of normal dentin at $\times 2500$ magnification. The normal dentin structure showed numerous dentinal tubules with regular arrangement. The elements mainly calcium and phosphorous are presented by weight $\%$ and atomic \%. The calcium level was reported to
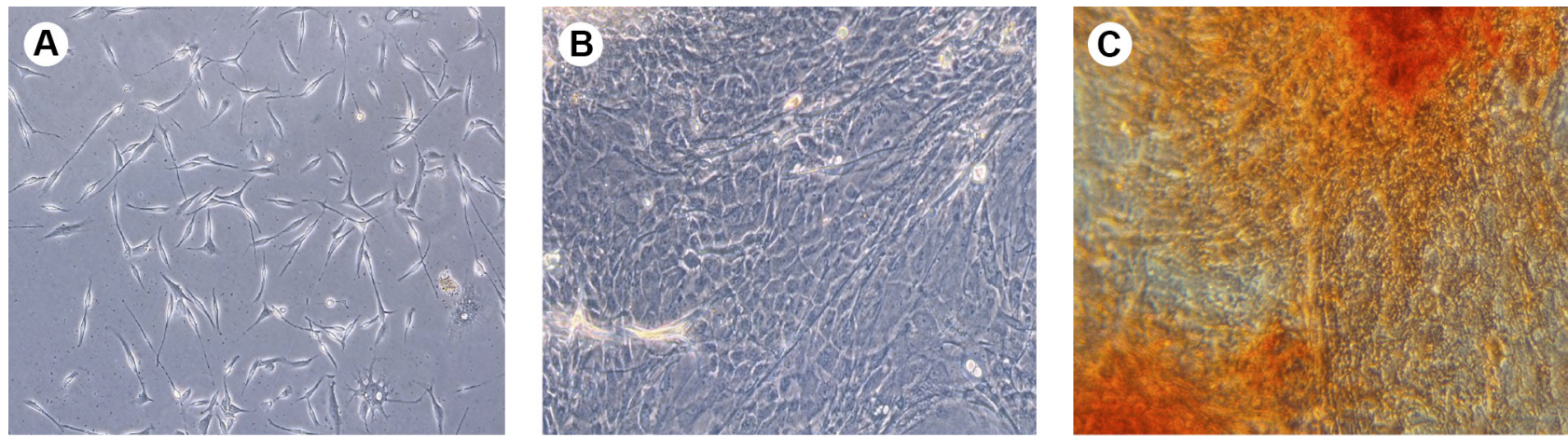

Figure 1. (A)-Phase contrast microscopic photomicrograph of DPSCs after 3 days of isolation showing scattered spindle shaped cells (100x), (B) Phase contrast microscopic photomicrograph of DPSCs after two weeks of induction of odontogenic differentiation with most of the cells assumed the polygonal shape (100x) and (C) Phase contrast microscopic photomicrograph of DPSCs showing positive Alizarin red Staining after two weeks of odontogenic differentiation. The presence of Orange red nodules stains is indicative of successful differentiation (100x).
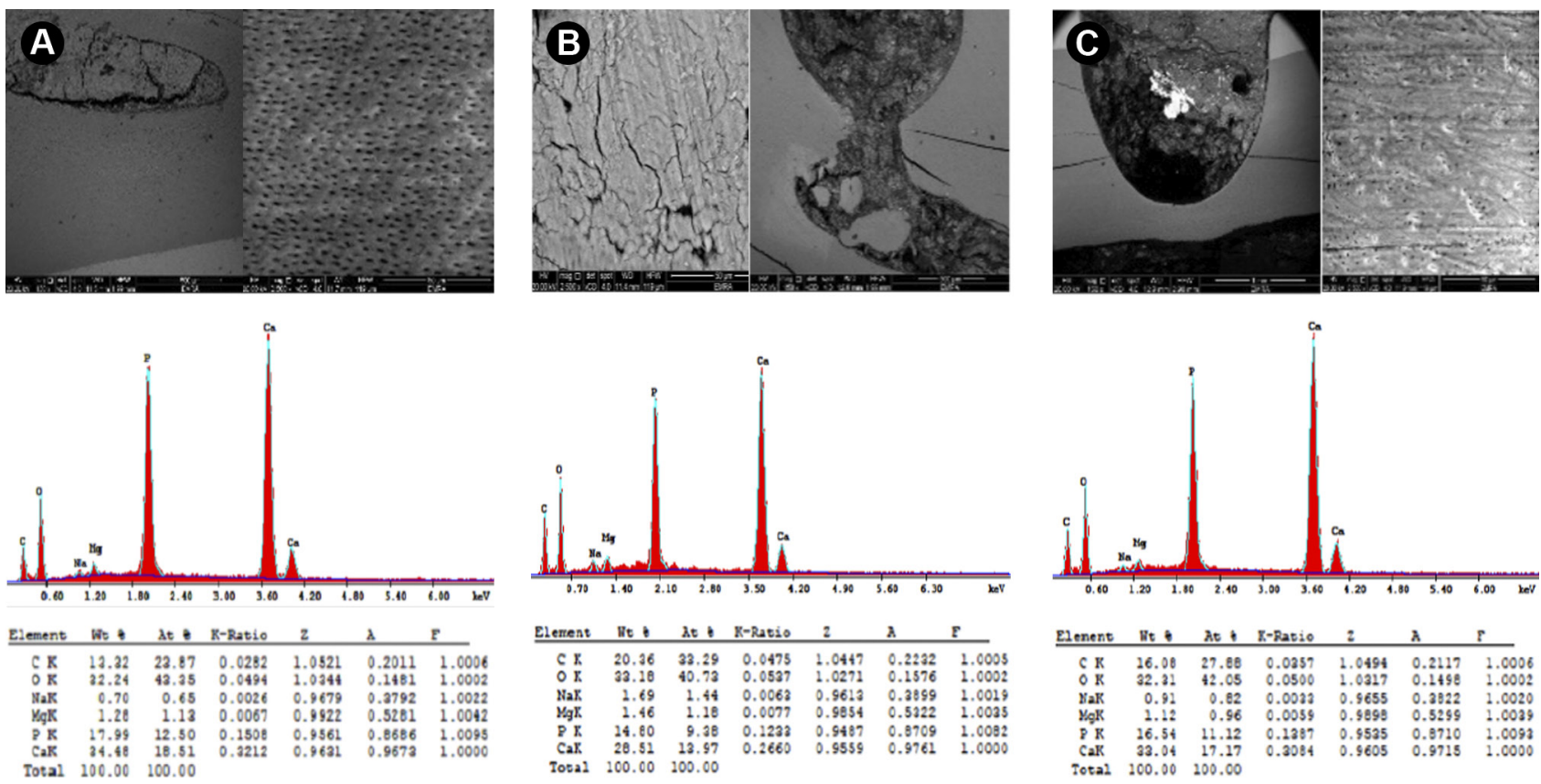

Figure 2. (A) EDAX microanalysis showing structure and mineral profile of normal dentin (B) EDAX microanalysis showing structure and mineral profile of reparative dentin formed calcium hydroxide group (C) EDAX microanalysis showing structure and mineral profile of regenerated. 
be $34.48 \mathrm{wt}, \%$, while the phosphorous level was $17.99 \mathrm{wt}, \%$.

Calcium Hydroxide Group: Figure (2-B) shows the structure and EDAX elemental analysis of hard tissue barriers formed in calcium hydroxide group. The formed hard tissue barrier revealed mixed dentin structure of amorphous (a tubular) and tubular reparative dentin.

Dental Pulp Stem Cells (Dpscs) Group: Figure (2-C) shows the structure and EDAX elemental analysis of hard tissue barriers formed in dental pulp stem cells group. The regenerated structure revealed normal dentin structure with fewer dentinal tubules of an irregular arrangement.

\section{EDAX Elemental Analysis of the Experimental Groups compared to Control}

Tables (1) and Figure (3A-C) show mean \pm standard

Table 1. Mean \pm SD of calcium, Phosphorus wt \% Ca/P ratio for calcium hydroxide, DPSCs groups in comparison to normal dentin

\begin{tabular}{|c|c|c|c|c|c|c|c|c|}
\hline & & \multirow{2}{*}{ Mean } & \multirow{2}{*}{ SD } & \multirow{2}{*}{$\mathrm{t}$} & \multirow{2}{*}{$\begin{array}{c}\text { Mean } \\
\text { Difference }\end{array}$} & \multicolumn{2}{|c|}{ 95\% Confidence } & \multirow{2}{*}{$\mathrm{p}$ value } \\
\hline & & & & & & Lower & Upper & \\
\hline \multirow{4}{*}{$\mathrm{Ca}$} & $\mathrm{Ca}(\mathrm{OH})_{2}$ & 26.9667 & 1.25097 & -10.403 & -7.51333 & -10.6209 & -4.4057 & $0.009^{*}$ \\
\hline & Stem Cells & 31.9567 & 1.33874 & -3.265 & -2.52333 & -5.8490 & 0.8023 & 0.082 \\
\hline & Control & 34.48 & & & & & & \\
\hline & $\mathrm{Ca}(\mathrm{OH})_{2}$ & 14.8467 & 0.46177 & -11.790 & -3.14333 & -4.2904 & -1.9962 & $0.007^{*}$ \\
\hline \multirow[t]{3}{*}{$\mathrm{P}$} & Stem Cells & 17.3933 & 0.86524 & -1.194 & -0.59667 & -2.7460 & 1.5527 & 0.335 \\
\hline & Control & 17.99 & & & & & & \\
\hline & $\mathrm{Ca}(\mathrm{OH})_{2}$ & 1.8167 & 0.11676 & -1.385 & -0.09333 & -0.3834 & 0.1967 & 0.3 \\
\hline \multirow[t]{2}{*}{$\mathrm{Ca} / \mathrm{P}$} & Stem Cells & 1.8367 & 0.16623 & -0.764 & -0.07333 & -0.4863 & 0.3396 & 0.525 \\
\hline & Control & 1.91 & & & & & & \\
\hline
\end{tabular}

*Significant deviation values of calcium weight percentage $(w t, \%)$, phosphorus $(w t, \%)$ and calcium/phosphorus ratio for calcium hydroxide and DPSCs groups in comparison to normal dentin. There was no significant difference in calcium, phosphorus wt, $\%$ and calcium/phosphorus ratio between calcium hydroxide, DPSCs group and normal dentin.

\section{Results of histological analysis Normal Dentin Structure (Control)}

In control group, specimens showed continuous regular layers of secondary and primary dentin separated by a line of demarcation. Dentinal tubules were highly organized and regularly arranged (Fig.4-A).

\section{Calcium Hydroxide Group}

Calcium hydroxide samples showed dentin bridge formation that was continuous and completely obliterated the exposure site in 6 samples. It was interrupted and incompletely obliterating the exposure site in 2 samples, while there was no dentin bridge noticed in 1 sample. At higher magnification (100x), there is a line of demarcation between the formed reparative dentin and the primary dentin. With higher magnification (x200), the reparative tissue exhibited mixed dentin structure with both amorphous (a-tubular) and tubular dentin. Tunnel defects were also observed within the formed reparative dentin (Fig. 4B).

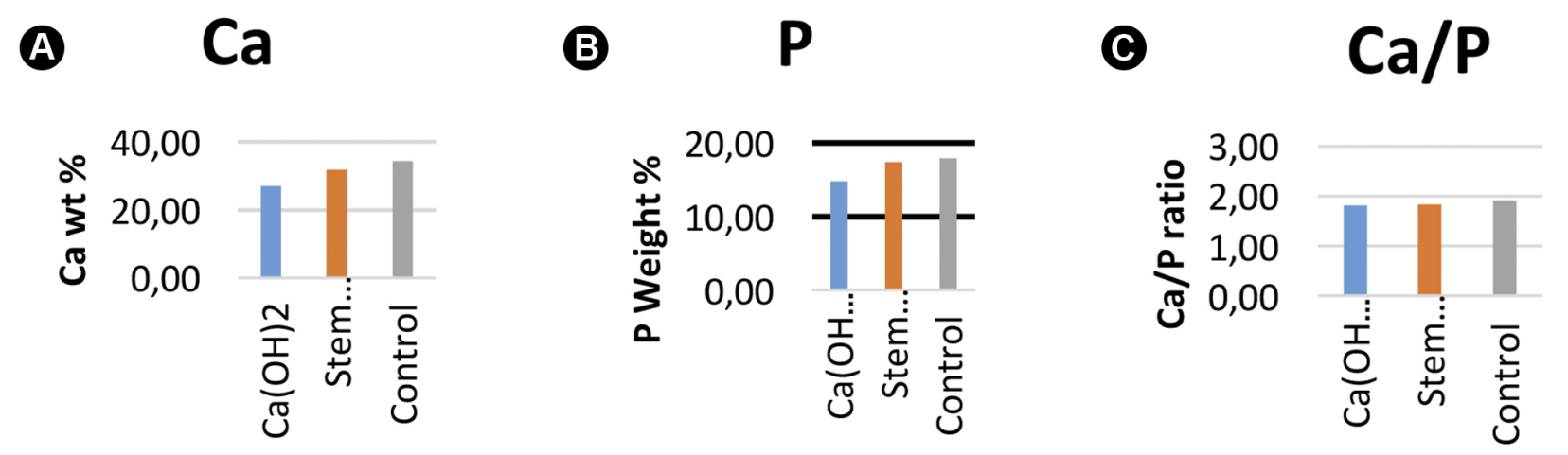

Figure 3. (A) Bar chart showing calcium wt \% for calcium hydroxide and DPSCs groups in comparison to normal dentin (B) Bar chart showing phosphorous wt \% for calcium hydroxide and DPSCs groups in comparison to normal dentin C) Bar chart showing $\mathrm{Ca} / \mathrm{P}$ ratio for calcium hydroxide and DPSCs groups in comparison to normal dentin. 


\section{DPSC Group}

In DPSCs group, eight samples showed continuous dentin bridge completely obliterating the exposure site and only one specimen showed no dentin bridge formation. At higher magnification $(100 x)$, there is a line of demarcation between the newly formed dentin and primary dentin. With higher magnification (200x), the newly formed dentin was similar to normal secondary dentin in terms of irregular arrangement of dentinal tubules (Fig. 4C).

\section{Discussion}

Although calcium hydroxide is considered the gold standard of the pulp capping materials, it cited three major causes of failure which are the porosity of the produced dentinal bridge, it adheres poorly to dentin and its inability to provide a long-term seal against microleakage (4).

Stem-cell-based tissue engineering has been performed in the animal model for many types of tissue regeneration. The animal model selected in this study was dogs because the mechanism of synthesis of dentin is the same as in the human beings despite the rate of reparative dentinogenesis may differ (16). Dogs are believed to be a suitable experimental model because their pulp is comparable to that of humans (17). In addition, the pulp size provides a suitable sample for the histopathological evaluation. Beside that dogs' dentition provides a good number of teeth in each animal; that allows the comparison of more than one material or technique in the same dog.

In the present study, removal of the dental pulp from the enclosed hard dental tissue is challenging. Therefore, a cut was performed around the cementoenamel junction to reveal the pulp chamber and the pulp tissue was gently separated from the crown and the root without requiring extraction or invasive surgical procedures. The used method could become a new non-invasive source of cell therapy. In this respect, there has been only one study that derived DPSCs from a fractured tooth without involving invasive surgical procedures (7). In this study, isolation of DPSCs by enzymatic digestion with collagenase type I allowed all cell types to be released from the tissue. Also, the mineralization rate and the amount of the produced mineralized matrix were higher compared to outgrowth cultures. This is consistent with previous studies (18). The odontogenic differentiation potential of DPSCs was enhanced by the addition of dexamethasone, ascorbic acid and $\beta$-glycerophosphate which accelerate the rate of odontogenic differentiation, which was assessed by Alzarin red staining for detection of calcium-rich deposits formed by the differentiated cells. Similar results were obtained in previous studies (19).

Interestingly, increased dentin sialo-phosphoprotein (DSPP), which is known as an odontoblast-specific gene responsible for encoding the two proteins, dentin sialoprotein and dentin phosphoprotein further confirmed their odontogenic differentiation ability. This is consistent with previous studies $(20,21)$. Therefore, in this study, DSPP was chosen as a marker for cell differentiation as it is regarded as a specific marker for odontoblast that was detected by qRT-PCR. The isolated DPSCs from each dog were transplanted over the exposure site in the same dog resembling an autologous cells model having the benefit of being free of any immune response or rejection (13).

Mechanical Pulp exposure was performed by the use of a sterile sharp probe because this technique avoids the extensive pulp damage caused by exposure during cutting with a bur and also this approach creates a pulp exposure of uniform size. Similar technique was used $(6,22,23)$. Hydroxyapatite/ $\beta$-tricalcium phosphate powder has been widely used as a scaffold that acts as a structural framework for cell seeding, adhesion, proliferation and spatial distribution because of their highly biocompatible nature and their ability to support the formation of hard
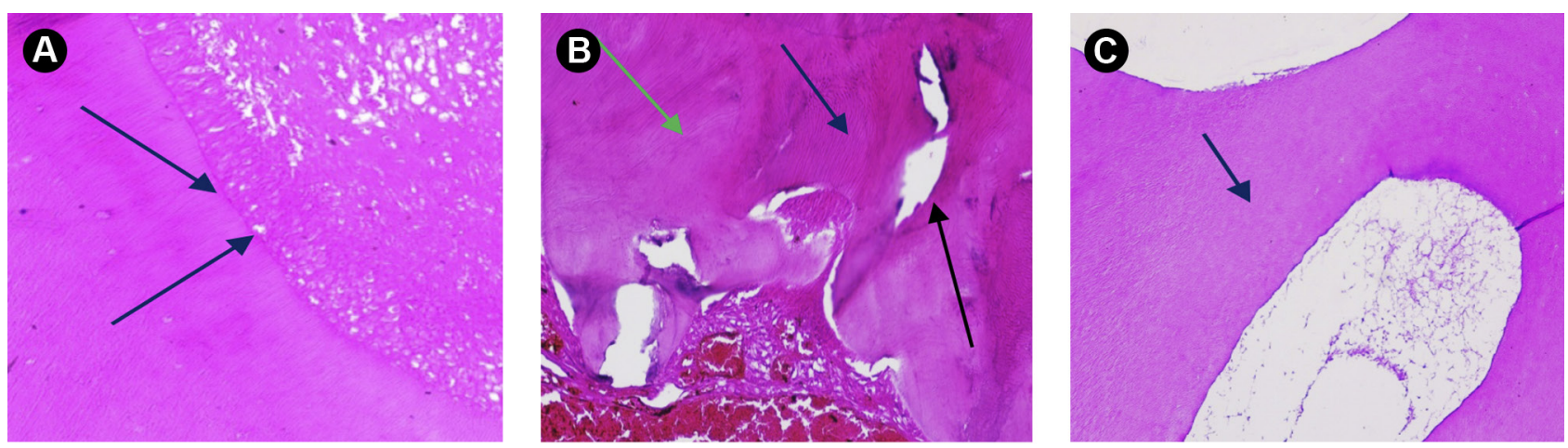

Figure 4. (A) A photomicrograph showing the line of demarcation between primary and secondary dentin of normal dentin (blue arrows) (HE 200x). (B) A photomicrograph of calcium hydroxide showing the mixed structure of the newly formed reparative dentin, a-tubular dentin (green arrow) and tubular dentin (blue arrow). Tunnel defects are present within the dentin bridge (black arrow) (HE 200x). C) A photomicrograph of DPSCs showing the line of demarcation between the newly formed dentin and the primary dentin (blue arrow) (HE 100x) 
tissue (24). Gold foil was used to cover DPSCs before glass ionomer coronal restoration to protect DPSCs from any chemical irritation caused by the applied restoration having the benefit of gold inertness on living tissues (6).

The three months observation period for the final judgment of the pulp capping procedures was suitable for histological detection of hard barrier formation as followed by most of the studies utilizing this animal model $(25,26)$. The clinical criteria are inadequate for evaluation of the long-term prognosis for teeth treated by pulp capping, also it is impossible to clinically diagnose teeth in which healing is complicated by inflammation. The formation of dentin bridge or a calcified barrier has been considered as one of the criteria for judging successful restoration whose formation can only be detected histologically (27). Therefore, critical evaluation of the results of pulp capping was histologically performed in this study. Many previous studies confirmed the formation of mineralized tissue following direct pulp capping, but little attention has been paid to their composition and mineral content, since small variations in tissue composition and even minor differences in mineral crystallinity can have a profound effects on tissue function. Therefore, the EDAX elemental $\vec{s}$ analysis was performed to study mineral composition within narrow areas of tissue since the main criterion of success in direct pulp capping procedures is the formation of dentin bridge or a calcified barrier. In this study, we analyzed the structure of normal dentin tissue of dog's teeth by scanning electron microscope SEM and EDAX elemental analysis and used these measurements as a comparison point for the structure of the formed mineralized tissue by calcium hydroxide and DPSCs. The mineral content of the dentin-like structure formed by DPSCs was not statistically significant difference from normal dentin. While, the calcific barrier formed by calcium hydroxide showed lower statistically significant mineral content both than normal dentin and the dentin-like structure.

In the present study formation of a calcified barrier over the exposure site was detected in calcium hydroxide group. The reparative hard tissue formed by calcium hydroxide showed an amorphous and a-tubular pattern that did not resemble the normal tubular dentin. These results are consistent with the findings of previous studies $(2,14,25-30)$.

The success of mesenchymal stem cells as DPSCs to form dentin-like structure can be attributed to their regeneration potential. Many previous animal and clinical studies suggest that the effect of DPSCs may not be limited only to the direct replacement of the damaged cells but also the guidance of regeneration by multiple effects on the tissueresident cells, including the enhancement of vascularization and the production of growth factors $(31,32)$.
The suitable number of stem cells necessary for dentin regeneration is not currently clear. Insufficient seeding of cells leads to less tissue regeneration. Conversely, too many cells may induce cell density inhibition. In this study, the cell number seeded on the scaffold was $2 \times 10^{6}$ with subsequent detection of dentin-like structure within the DPSCs $/ \beta-$ TCP group. This may facilitate the development of DPSCs $/ \beta-$ TCP constructs efficiently, with lower cell numbers that are practical for clinic use. Greater cell number, as much as $5.0 \times 10^{6}$ was used (6), and smaller cell number as lower as $2.2 \times 105$ was used (33) with positive results regarding dentin bridge formation.

Direct pulp capping by stem cells has shown a promising generative potential for regaining normal dentin at the exposure site while calcium hydroxide had also the ability to induce reparative but amorphous dentin following pulp capping.

\section{Resumo}

0 processo de capeamento pulpar direto é um método terapêutico que visa a manutenção da vitalidade e saúde da polpa, usando um material biocompatível colocado diretamente sobre a polpa exposta. 0 objetivo deste estudo foi avaliar e comparar o efeito do capeamento pulpar direto usando células-tronco da polpa dentária (CTPDs) ou hidróxido de cálcio sobre o tecido da dentina formação. Três cães sem raça definida foram utilizados como modelo experimental. Duas cavidades de acesso foram preparados nos quartos pré-molares inferiores direito e esquerdo em todos os cães para expor e extirpar os tecidos pulpares que foram processados em laboratório para obter suspensões de uma célula única. As células isoladas foram cultivadas em meio odontogênico para posterior diferenciação. Os dentes superiores ( 3 incisivos e um canino) do respectivo cão foram submetidos ao preparo de cavidades classe $V$ para expor suas polpas, as quais foram atribuidas a 2 grupos de 12 dentes cada (grupo I - capeamento pulpar com hidróxido de cálcio) e (grupo II - capeamento pulpar com CTPDs). Os dentes operados foram extraídos após 3 meses e processado para exames histológicos e por microscopia eletrônica de varredura. Os espécimes foram submetidos a análises elementares de cálcio e fósforo. Análise elementar por EDX revelaram diferenças significativas no peso de cálcio e fósforo, \% na massa reparadora dentina do grupo tratado com hidróxido de cálcio, o que foi confirmado histologicamente. 0 capeamento pulpar com CTPDs mostrou potencial promissor para recuperar a dentina normal.

\section{References}

1. Asgary S, Parirokh M, Eghbal MJ, Ghoddusi J. SEM evaluation of pulp reaction to different pulp capping materials in dog's teeth. Iran Endod J 2006;1:117-123.

2. Aljandan $B, A l H a s s a n ~ H$, Saghah $A$, Rasheed $M$, Ali A A. The effectiveness of using different pulp-capping agents on the healing response of the pulp. Indian J Dent Res 2012;23:633-637.

3. Edwards PC, Mason JM. Gene-enhanced tissue engineering for dental hard tissue regeneration: (2) dentin-pulp and periodontal regeneration. Head Face Med 2006;2:16.

4. Nowicka A, Wilk G, Lipski M, Kołecki J, Buczkowska-Radlińska J. Tomographic evaluation of reparative dentin formation after direct pulp capping with $\mathrm{Ca}(\mathrm{OH}) 2$, MTA, Biodentine, and dentin bonding system in human teeth. J Endod 2015;41:1234-1240.

5. Obeid M, Saber SEDM, Ismael AED, Hassanien E. Mesenchymal stem cells promote hard-tissue repair after direct pulp capping. J Endod 2013;39:626-631.

6. Gronthos S, Mankani M, Brahim J, Robey PG, Shi S. Postnatal human 
dental pulp stem cells (DPSCs) in vitro and in vivo. Proc Natl Acad Sci U S A 2000;97:13625-13630.

7. Huang AHC, Chen YK, Chan AWS, Shieh TY, Lin LM. Isolation and characterization of human dental pulp stem/stromal cells from nonextracted crown-fractured teeth requiring root canal therapy. J Endod 2009;35:673-681.

8. Alsulaimani RS, Ajlan SA, Aldahmash AM, Alnabaheen MS, Ashri NY. Isolation of dental pulp stem cells from a single donor and characterization of their ability to differentiate after 2 years of cryopreservation. Saudi Med J 2016;37:551-560.

9. Zhang W, Walboomers XF, Van Kuppervelt TH, Daamen WF, Van Damme $P A, B i a n Z$, et al. In vivo evaluation of human dental pulp stem cells differentiated towards multiple lineages. J Tissue Eng Regen Med 2008;2:117-125.

10. Volponi AA, Gentleman E, Fatscher R, Pang YWY, Gentleman M. M, Sharpe PT. Composition of mineral produced by dental mesenchymal stem cells. J Dent Res 2015; 94:1568-1574.

11. Mitsiadis TA, Orsini G,Jimenez-Rojo L.Stem cell-based approaches in dentistry. Eur Cell Mater 2015;30:248-257.

12. Miran S, Mitsiadis TA, Pagella P. Innovative Dental Stem Cell-Based Research Approaches: The Future of Dentistry. Stem Cells Int. 2016; $1-11$.

13. Davies OG, Cooper PR, Shelton RM, Smith AJ, Scheven BA. A comparison of the in vitro mineralisation and dentinogenic potential of mesenchymal stem cells derived from adipose tissue, bone marrow and dental pulp. J Bone Miner Metab 2015; 33:371-382.

14. Alkhalil M, Smajilagic A, Redzic A. Human dental pulp mesenchymal stem cells isolation and osteoblast differentiation. Medicinski glasnik J 2015;12:27-32

15. Koliniotou-Koumpia E, Tziafas D. Pulpal responses following direct pulp capping of healthy dog teeth with dentine adhesive systems. J Dent 2005;33:639-647.

16. Veis A. The role of dental pulp through on the session on pulp repair processes. J Dent Res 1985;64:552-554.

17. Branstrom $M$, Nyborg $H$, Stromberg T. Experiments with pulp capping. Int. J. Oral Surg 1979;48:347-352.

18. Yildirim S. Dental pulp stem cells. 2012; Springer Science \&t Business Media

19. Iohara $K$, Nakashima $M$, Ito $M$, Ishikawa $M$, Nakasima $A$, Akamine $A$. Dentin regeneration by dental pulp stem cell therapy with recombinant human bone morphogenetic protein 2. J Dent Res 2004 83:590-595.

20. Dissanayaka WL, Zhu X, Zhang C, Jin L. Characterization of dental pulp stem cells isolated from canine premolars. J Endod 2011;37:1074-1080.

21. Guo S, Lim D, Dong Z, Saunders TL, Ma PX, Marcelo CL, et al. Dentin sialophosphoprotein: a regulatory protein for dental pulp stem cell identity and fate. Stem Cells Dev 2014;23:2883-2894.
22. Decup F, Six N, Palmier B, Buch D, Lasfargues JJ, Salih E, et al. Bone sialoprotein-induced reparative dentinogenesis in the pulp of rat's molar. Clin Oral Investig 2000;4:110-119.

23. Orhan EO, Maden M, Senguüven B. Odontoblast- like cell numbers and reparative dentine thickness after direct pulp capping with plateletrich plasma and enamel matrix derivative: a histomorphometric evaluation. Int Endod J 2012;45:317-325:

24. Zhang W, Walboomers XF, Wolke JGC, Bian Z, Fan MW, Jansen JA. Differentiation ability of rat postnatal dental pulp cells in vitro. Tissue Eng 2005;11:357-368.

25. Lu Y, Liu T, Li X, Li H, Pi G. Histologic evaluation of direct pulp capping with a self-etching adhesive and calcium hydroxide in beagles. Oral Surg Oral Med Oral Pathol Oral Radiol Endod 2006;102 e78-e84.

26. Reston EG, de Souza Costa CA. Scanning electron microscopy evaluation of the hard tissue barrier after pulp capping with calcium hydroxide, mineral trioxide aggregate (MTA) or ProRoot MTA. Aust Endod J 2009;35:78-84.

27. Parolia A, Kundabala M, Rao NN, Acharya SR, Agrawal P, Mohan M, et al. A comparative histological analysis of human pulp following direct pulp capping with Propolis, mineral trioxide aggregate and Dycal Aust Endod J 2010;55:59-64.

28. Da Silva LA, de Freitas AC, de Carvalho FK, de Queiroz AM, Nelson-Filho P, Porto-Neto ST. Direct pulp capping with a self-etching adhesive system: histopathologic evaluation in dogs' teeth. Oral Surg Oral Med Oral Pathol Oral Radiol Endod 2009;108:e34-e40.

29. Al-Hezaimi K, Salameh Z, Al-Fouzan K, Al Rejaie M, Tay FR. Histomorphometric and micro-computed tomography analysis of pulpal response to three different pulp capping materials. J Endod 2011;37:507-512.

30. Akhavan A, Arbazadeh F, Bouzari M, Razavi SM, Davoudi A. Pulp response following direct pulp capping with dentin adhesives and mineral trioxide aggregate: An animal study. Iran Endod 2017;12:226230.

31. Chamberlain G, Fox J, Ashton B, Middleton J. Concise review: mesenchymal stem cells: their phenotype, differentiation capacity, immunological features, and potential for homing. Stem Cells 2007;25:2739-2749.

32. Huang GTJ. Dental pulp and dentin tissue engineering and regeneration-advancement and challenge. Front Biosci (Elite Ed) 2011;3:788.

33. Zheng $Y$, Wang $X Y$, Wang $Y M$, Liu $X Y$, Zhang $C M$, Hou BX, et al. Dentin regeneration using deciduous pulp stem/progenitor cells. J Dent Res 2012;91:676-682. 